\title{
PENGARUH MODEL POLYA TERHADAP KEMAMPUAN PEMECAHAN MASALAH MATEMATIKA SISWA KELAS V SD
}

\author{
Pt. Nanci Riastini1 ${ }^{1}{ }^{*}$, K Kd. Agus Mustika² \\ 1,2 Jurusan PGSD, FIP Universitas Pendidikan Ganesha
}

\begin{abstract}
This study aimed at investigating different performances in solving mathematical problems of fifth grade students who attends learning process in polya model and students who attends learning process which not used polya model in Cluster I Airlangga Mendoyo Sub-district in academic year 2016/2017. This study was a quasiexperimental research that is post-test only control group design. The population of this study was all of fifth grade students of elementary school in Cluster I Airlangga Mendoyo Sub-district. The population of the study consisted of eleven classes with 183 students. Random sampling technique was used to determine the sample of the study. The data collection was conducted through test. The instrument of the data collection was essay test. The data collected through test was analyzed descriptively to find out the mean, median, mode and inferentially by conducting t-test (polled variance). The result of hypothesis testing shows that there is significant difference of students' ability in solving mathematical problem between students who attend learning process in polya model and students who attend a learning process which not use polya model. The finding indicates that learning process in polya model make students to actively participate in discussion to solve mathematical problem presented. Furthermore, the phases of polya model train students to work systematically in solving the problem. Thus, polya model give significant effect on fifth grade students' ability in solving mathematical problem in Cluster I Airlangga Mendoyo Sub-district in academic year 2016/2017.
\end{abstract}

Keywords:

Polya Model, Problem-

Solving Ability,

Mathematics

\section{Introduction}

Matematika merupakan suatu ilmu yang memiliki peran penting dalam kehidupan. Peran Matematika tersebut dapat dilihat dari dua sisi, yaitu dari sisi kehidupan praktis dan sisi Matematika sebagai proses berpikir. Dari sisi kehidupan praktis, Matematika digunakan dalam menjalankan berbagai aktivitas, diantaranya menghitung jumlah suatu barang, mengukur suatu benda, melakukan transaksi jualbeli, dan menyajikan informasi yang bersifat kuantitatif. Dari sisi Matematika sebagai proses berpikir, Matematika berperan untuk melatih kemampuan berpikir logis, kritis, dan sistematis. Hal tersebut ditegaskan oleh Japa dan Suarjana (2014:3) yang menyatakan bahwa, "dibelajarkannya matematika kepada semua peserta didik mulai dari tingkat sekolah dasar adalah untuk membekali mereka berbagai kemampuan seperti: kemampuan berpikir logis, analitis, sistematis, kritis dan kreatif, serta kemampuan bekerjasama". Kemampuan-kemampuan tersebut nantinya akan sangat dibutuhkan dalam memecahkan berbagai masalah, khususnya yang berhubungan dengan Matematika.

Mengingat peran Matematika yang begitu penting, maka seyogyanya pembelajaran Matematika perlu mendapat perhatian. Seperti yang telah dikemukakan sebelumnya, pembelajaran Matematika hendaknya dirancang agar siswa mampu mengembangkan kemampuan berpikir logis, analitis, sistematis, kritis dan kreatif, serta kemampuan bekerjasama. Selain kemampuan-kemampuan tersebut, ada beberapa kemampuan yang perlu dimiliki oleh siswa, yang salah satunya yaitu kemampuan pemecahan masalah. NCTM (2000:52) mengemukakan bahwa, "problem solving is an integral part of all mathematics learning, and so it should not be an isolated part of the mathematics program". Artinya, pemecahan masalah merupakan bagian integral dalam pembelajaran Matematika, sehingga tidak boleh dipisahkan dari pembelajaran Matematika. Hal tersebut dapat dimengerti bahwasanya pemecahan masalah bukan hanya menjadi tujuan pembelajaran Matematika, tetapi juga alat untuk memahami Matematika itu sendiri. 
Selanjutnya, O'Daffer, dkk. (2008:41) mengungkapkan bahwa, "problem solving is a process by which an individual uses previously learned concepts, facts, and relationships, along with various reasoning skills and strategies, to answer a question or questions about a situation". Hal tersebut dapat diartikan bahwa pemecahan masalah adalah proses yang dilakukan seorang individu untuk menjawab pertanyaan tentang suatu situasi menggunakan konsep-konsep, fakta-fakta, dan hubungan-hubungan yang dipelajari sebelumnya, serta menggunakan berbagai keterampilan penalaran dan strategi.

Mendukung pendapat di atas, Krulik dan Rudnick (dalam Barb dan Quinn, 1997:2) menyatakan bahwa "problem solving has been defined as a means by which one applies previous knowledge, skills, and understanding to determine an answer to a question or unfamiliar situation". Artinya, pemecahan masalah merupakan proses menerapkan pengetahuan, keterampilan, dan pemahaman yang telah dimiliki sebelumnya ke dalam suatu situasi yang baru. Adapun kemampuan pemecahan masalah berarti kemampuan seseorang dalam melakukan proses penyelesaian suatu masalah dengan memanfaatkan pengetahuan yang telah dimilikinya.

Melalui pemecahan masalah, siswa dapat memperoleh pengalaman belajar yang bermakna. Pengalaman belajar yang bermakna tersebut akan tumbuh sebagai dampak dari adanya keterlibatan siswa dalam menghubungkan konsep Matematika yang telah dipelajari untuk menyelesaikan suatu masalah. Namun, kemampuan pemecahan masalah siswa di Indonesia masih lemah. Sebagai bukti, hasil Programme for International Student Assesment (PISA) Matematika tahun 2012 menunjukkan bahwa sebanyak total $75,7 \%$ dari siswa Indonesia yang mengikuti PISA tergolong memiliki kemampuan yang rendah. Sebanyak 42,3\% dari siswa tersebut termasuk ke dalam kategori di bawah level 1 atau dengan kata lain memiliki kemampuan pemecahan masalah yang sangat terbatas. Sebanyak 33,4\% lainnya termasuk ke dalam kategori level 1 yang berarti hanya mampu mengerjakan soal-soal langsung yang menyediakan kondisi yang sederhana (OECD, 2016).

Permasalahan mengenai lemahnya kemampuan pemecahan masalah Matematika juga terjadi di kelas V SD di Gugus I Airlangga Kecamatan Mendoyo Tahun Pelajaran 2016/2017. Hal tersebut tercermin dari hasil tes pengumpulan data kemampuan pemecahan masalah Matematika yang disajikan pada Tabel 1.

Tabel 1. Hasil Tes Pengumpulan Data Kemampuan Pemecahan Masalah Matematika Siswa Kelas V SD di Gugus I Airlangga Kecamatan Mendoyo

\begin{tabular}{clc}
\hline No & \multicolumn{1}{c}{ Nama Sekolah } & Rata-rata Skor \\
\hline 1 & SDN 1 Pohsanten & 5,97 \\
2 & SDN 2 Pohsanten & 6,00 \\
3 & SDN 3 Pohsanten & 5,40 \\
4 & SDN 4 Pohsanten & 10,63 \\
5 & SDN 5 Pohsanten & 5,00 \\
6 & SDN 1 Mendoyo Dauh Tukad (Kelas A) & 12,40 \\
7 & SDN 1 Mendoyo Dauh Tukad (Kelas B) & 6,16 \\
8 & SDN 2 Mendoyo Dauh Tukad & 7,88 \\
9 & SDN 3 Mendoyo Dauh Tukad & 7,80 \\
10 & SDN 1 Mendoyo Dangin Tukad & 6,55 \\
\hline
\end{tabular}

(Sumber: Daftar Skor Tes Pengumpulan Data Kemampuan Pemecahan Masalah Matematika Siswa Kelas V SD di Gugus I Airlangga Kecamatan Mendoyo, 2017)

Berdasarkan hasil tes pada Tabel 1, apabila rata-rata skor dikonversikan terhadap skala lima teoretik, maka rata-rata skor kemampuan pemecahan masalah siswa secara keseluruhan berada pada kategori rendah hingga sedang. Namun, pada tiga kelompok kelas memiliki rata-rata skor yang termasuk kategori tinggi. Hal ini menunjukkan bahwa sebagian besar kemampuan pemecahan masalah Matematika siswa belum maksimal. Permasalahan di atas terjadi karena siswa tidak memahami masalah yang disajikan pada soal. Banyak siswa yang tidak mampu menyelesaikan soal cerita tentang konversi satuan panjang padahal soal tersebut tergolong mudah. Bahkan, tidak sedikit pula siswa yang secara sembarang mengoperasikan bilangan-bilangan yang tercantum pada soal.

Selain faktor dari siswa sendiri, faktor pembelajaran yang dilakukan guru juga menjadi salah satu faktor penyebab siswa mengalami kesulitan dalam pemecahan masalah Matematika. Berdasarkan hasil observasi yang dilakukan pada tanggal 3 - 7 Januari 2017, dapat diketahui bahwa guru jarang memberikan soal-soal nonrutin, sehingga ketika siswa dihadapkan pada soal-soal nonrutin maka siswa mengalami kesulitan untuk menyelesaikannya. Selain itu, peran guru dalam kelas lebih dominan sehingga 
siswa cenderung lebih berperan sebagai penerima informasi secara pasif. Akibatnya konsep-konsep yang telah dibelajarkan menjadi mudah dilupakan siswa.

Pembelajaran dengan metode ceramah, penugasan, dan diskusi yang biasanya dilakukan di sekolah, kurang mampu mengembangkan kemampuan siswa dalam memecahan masalah. Apabila siswa dihadapkan pada suatu masalah Matematika, proses pemecahan masalah yang dilakukan cenderung kurang sistematis. Hal tersebut berdampak pada terjadinya kekeliruan dalam proses dan hasil/jawaban yang diperoleh. Oleh karena itu, pembelajaran pemecahan masalah Matematika perlu dirancang untuk supaya pemecahan masalah dalam pembelajaran Matematika dapat memfasilitasi siswa untuk memperoleh pengalaman belajar yang bermakna. Selain itu, dalam proses pemecahan masalah itu sendiri perlu dirancang sedemikian rupa agar siswa dapat mengembangkan kemampuan berpikir logis, analitis, sistematis, kritis dan kreatif. Mengacu pada hal tersebut, suatu model pembelajaran yang tepat perlu dipilih sebagai sarana untuk memandu proses pemecahan masalah Matematika.

Salah satu model yang sesuai untuk mengembangkan kemampuan pemecahan masalah Matematika yaitu model Polya. Lesh dan Zawojewski (dalam Hensberry dan Jacobbe, 2012:62) mengatakan bahwa, "the heuristics are intended to help students go beyond current ways of thinking about a problem ... Polya's heuristics can be thought of as providing a language to help problem solvers think back about their problem-solving experiences". Artinya, model Polya merupakan suatu prosedur analitis yang dimaksudkan untuk membantu siswa agar bisa melebihi batasan cara berpikir siswa sekarang mengenai suatu masalah. Hensberry dan Jacobbe (2012:62) menambahkan bahwa, "the heuristics thus allow students to describe their processes, reflect on them, and eventually develop flexible thinking and skills that can be drawn upon in future problem-solving situations". Artinya, melalui model Polya memungkinkan siswa menjelaskan proses, merefleksi, dan pada akhirnya mengembangkan pemikiran serta keterampilan yang fleksibel yang dapat digunakan dalam situasi pemecahan masalah berikutnya.

Model Polya dirasa sesuai karena tahapan-tahapannya memberikan tuntunan kepada siswa untuk dapat menyelesaikan suatu masalah Matematika. Polya (dalam Billstein dkk., 2007:4) mengungkapkan bahwa tahapan-tahapan model Polya meliputi, "understanding the problem, devising a plan, carrying out the plan, looking back". Dalam rangka memecahkan suatu masalah sudah tentu harus memahami masalah itu terlebih dahulu. Sebagaimana dikemukakan Billstein, dkk. (2007:3), "to solve a problem, we must first understand both the task and the given information. Next, it is helpful to determine a strategy to accomplish the task. Once we arrive at a solution, we should determine whether the solution makes sense and is reasonable". Pemahaman terhadap suatu masalah akan bermanfaat untuk menentukan cara yang dapat dilakukan untuk menyelesaikan masalah. Pada tahap understanding the problem, Aisyah, dkk. (2007:5.21) menyebutkan bahwa ada beberapa pertanyaan yang perlu dimunculkan untuk membantu siswa memahami masalah diantaranya, "apakah yang diketahui dari soal?, apakah yang ditanyakan soal?, apakah saja informasi yang diperlukan?, bagaimana akan menyelesaikan soal?".

Selanjutnya, setelah siswa memahami masalah yang disajikan, siswa memilih strategi pemecahan masalah yang sesuai. Prihandoko (2005:261) mengatakan bahwa, "langkah ini berkenaan dengan pengorganisasian konsep-konsep yang bersesuaian untuk menyusun strategi, termasuk di dalamnya penentuan sarana yang dipergunakan dalam pemecahan masalah". Billstein, dkk. (2007:4) mengatakan bahwa pada devising a plan, hal yang dapat dilakukan yaitu, "examine related problems and determine if the same technique applied to them can be applied to the current problem". Artinya, siswa dapat meninjau kembali masalah serupa yang pernah dipecahkan sebelumnya dan menentukan apakah teknik yang sama dapat diterapkan pada masalah yang sedang dipecahkan sekarang. Selain itu, siswa juga dapat mengerjakan masalah serupa yang lebih sederhana untuk menambah wawasan untuk dapat menemukan solusi dari permasalahan utama.

Rencana yang telah disusun pada tahap dua kemudian diimplementasikan untuk mendapatkan sebuah penyelesaian. Polya (dalam Hensberry dan Jacobbe, 2012:63) mengatakan bahwa, "carrying out the plan thus includes computation as well as pausing after each step to check one's work and ensuring that the chosen plan is still the best choice". Artinya, pada tahap ini siswa melakukan perhitungan berdasarkan rencana yang telah dibuat. Selanjutnya, siswa memeriksa tiap langkah yang telah dikerjakan dan memastikan bahwa rencana yang dipilih merupakan pilihan yang tepat untuk menyelesaikan masalah.

Pada tahap terakhir yaitu looking back, Musser, dkk. (2008:6) menyatakan ada 3 pertanyaan yang perlu dimunculkan diantaranya, "1) Is your solution correct? Does your answer satisfy the statement of the problem?, 2) Can you see an easier solution?, 3) Can you see how you can extend your solution to a more general case?". Pertanyaan-pertanyaan tersebut dapat diartikan yaitu 1) apakah jawaban yang didapat sudah benar?, 2) apakah ada penyelesaian yang lebih mudah?, dan 3) apakah penyelesaian yang diperoleh dapat digeneralisasikan pada kasus yang lebih umum?

Mengacu pada langkah-langkah model Polya, siswa akan diarahkan untuk memiliki kemampuan berpikir logis, analitis, sistematis, kritis dan kreatif dalam pemecahan masalah. Berkaitan dengan 
penerapan langkah-langkah model Polya tersebut, Saiful (dalam Marlina, 2013:44) mengatakan bahwa, "siswa akan terbiasa untuk mengerjakan soal-soal yang tidak hanya mengandalkan ingatan yang baik saja, tetapi siswa diharapkan dapat mengaitkannya dengan situasi nyata yang pernah dialaminya atau yang pernah dipikirkannya". Selain itu, model Polya juga dapat mengembangkan rasa ingin tahu, perhatian dan minat, serta menumbuhkan sikap ulet dan percaya diri dalam pemecahan masalah.

Apabila siswa mengikuti langkah pemecahan masalah menggunakan model Polya, diduga akan berpengaruh terhadap kemampuan pemecahan masalah Matematika siswa. Akan tetapi, besarnya pengaruh belum dapat diketahui secara pasti. Oleh karena itu, perlu dilakukan penelitian yang bertujuan untuk untuk mengetahui perbedaan kemampuan pemecahan masalah Matematika antara kelompok siswa yang mengikuti pembelajaran menggunakan model Polya dan kelompok siswa yang mengikuti pembelajaran tidak menggunakan model Polya pada siswa kelas V SD di Gugus I Airlangga Kecamatan Mendoyo Tahun Pelajaran 2016/2017.

\section{Method}

Penelitian ini dilakukan di kelas V SD di Gugus I Airlangga, yang terletak di Kecamatan Mendoyo, Kabupaten Jembrana. Penelitian ini dimulai dari bulan Januari sampai dengan bulan Juni 2017. Penelitian ini dikategorikan sebagai penelitian eksperimen semu (quasi experiment) karena tidak semua variabel (gejala yang muncul) dan kondisi eksperimen dapat dikontrol secara ketat. Desain penelitian yang digunakan dalam penelitian ini adalah post-test only control group design.

Populasi dalam penelitian ini adalah seluruh kelas V SD di Gugus I Airlangga Kecamatan Mendoyo Tahun Pelajaran 2016/2017. Selanjutnya, penentuan sampel dilakukan dengan teknik simple random sampling. Cara penarikan sampel menggunakan sistem undian. Langkah penentuan sampel diawali dengan melakukan uji kesetaraan populasi menggunakan analisis varians satu jalur (ANAVA A). Data yang digunakan yaitu hasil tes pemecahan masalah Matematika. Random dilakukan bukan terhadap individu melainkan terhadap kelas. Hal ini dikarenakan tidak memungkinkan untuk melakukan random terhadap individu karena individu-individu sudah terdistribusi ke dalam kelas-kelas. Kemudian, pada kelas eksperimen diberikan perlakuan dengan model Polya, sedangkan pada kelas kontrol tidak diberikan perlakuan (pembelajaran tidak menggunakan model Polya). Selanjutnya, post-test diberikan kepada kelompok eksperimen maupun kelompok kontrol.

Hasil uji kesetaraan menggunakan ANAVA A menunjukkan bahwa populasi tidak setara, sehingga dilakukan uji lanjut antar dua kelas menggunakan uji $t$-scheffe. Dari hasil perhitungan diperoleh 19 pasang kelas yang setara. Kelas yang setara tersebut kemudian dipilih secara acak 1 pasang kelas yang akan digunakan sebagai sampel, menggunakan teknik undian. Selanjutnya, kelas yang keluar sebagai sampel diundi kembali untuk menentukan kelas yang digunakan sebagai kelompok eksperimen dan kelompok kontrol. Hasil pengundian sampel, diperoleh SD Negeri 1 Pohsanten sebagai kelompok eksperimen dan SD Negeri 1 Mendoyo Dangin Tukad sebagai kelompok kontrol.

Data yang dikumpulkan dalam penelitian ini adalah data mengenai kemampuan pemecahan masalah Matematika. Data tersebut dikumpulkan menggunakan metode tes. Menurut Agung (2014:92), metode tes merupakan "cara memperoleh data yang berbentuk suatu tugas yang harus dikerjakan seseorang atau sekelompok orang yang dites (testee), dan dari tes dapat menghasilkan suatu skor (interval)". Instrumen yang digunakan dalam penelitian ini adalah tes kemampuan pemecahan masalah Matematika, yang berupa soal uraian.

Pengujian instrumen penelitian dilakukan dengan melakukan pengujian validitas isi melalui uji pakar. Selanjutnya, instrumen diujicoba di lapangan untuk mengetahui validitas empiris tes, reliabilitas tes, daya beda butir tes, dan taraf kesukaran butir tes. Data kemampuan pemecahan masalah Matematika siswa dianalisis menggunakan analisis statistik deskriptif dan inferensial. Analisis statistik deskriptif dilakukan dengan menghitung mean, median, dan modus. Adapun analisis statistik inferensial untuk menguji hipotesis dilakukan dengan menggunakan uji-t sampel independent (tidak berkorelasi). Sebelum melakukan uji hipotesis, terlebih dahulu dilakukan pengujian asumsi terhadap data kemampuan pemecahan masalah Matematika siswa yang meliputi uji normalitas sebaran data dan uji homogenitas varians. Setelah diketahui data berdistribusi normal dan varians homogen, maka sesuai dengan ketentuan, dilakukan uji hipotesis menggunakan uji-t (polled varians).

\section{Results And Discussion}

Berdasarkan hasil analisis data yang telah dilakukan, disajikan rekapitulasi data kemampuan pemecahan masalah Matematika siswa kelompok eksperimen dan kelompok kontrol pada Tabel 3. 
Tabel 3. Rekapitulasi Hasil Perhitungan Skor Kemampuan Pemecahan Masalah Matematika Siswa

\begin{tabular}{lccc}
\hline \multicolumn{1}{c}{ Kelompok } & Mean (M) & Median (Md) & Modus (Mo) \\
\hline Eksperimen & 33,89 & 34,06 & 34,70 \\
Kontrol & 29,16 & 29,10 & 24,17 \\
\hline
\end{tabular}

Mengacu pada Tabel 3, secara deskriptif mean kelompok eksperimen lebih tinggi dibandingkan kelompok kontrol. Selanjutnya, apabila mean dikonversikan terhadap skala lima teoretik, dapat diketahui bahwa mean kelompok eksperimen berada pada kategori sedang dan mean kelompok kontrol berada pada kategori rendah. Selanjutnya, untuk melihat kecenderungan skor yang diperoleh siswa, maka data skor post test kemampuan pemecahan masalah Matematika siswa disajikan ke dalam kurva poligon. Kurva poligon skor post test kemampuan pemecahan masalah matematika kelompok eksperimen disajikan pada Gambar 1.

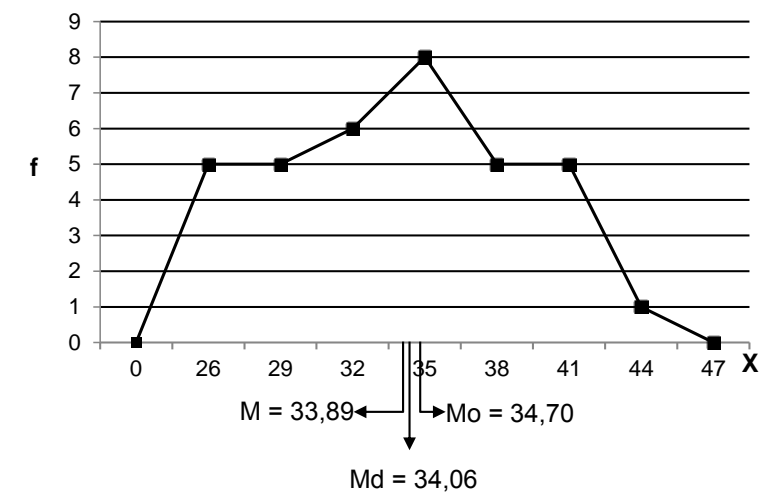

Gambar 1. Kurva Poligon Skor Post Test Kemampuan Pemecahan Masalah Matematka Kelompok Eksperimen

Berdasarkan Gambar 1, dapat diketahui bahwa modus lebih besar daripada median dan mean $(\mathrm{Mo}>\mathrm{Md}>\mathrm{M})$, sehingga kurva yang terbentuk yaitu kurva juling negatif. Hal ini berarti bahwa sebagian besar skor cenderung tinggi. Kemudian, kurva poligon skor post test kemampuan pemecahan masalah matematika kelompok kontrol disajikan pada Gambar 2.

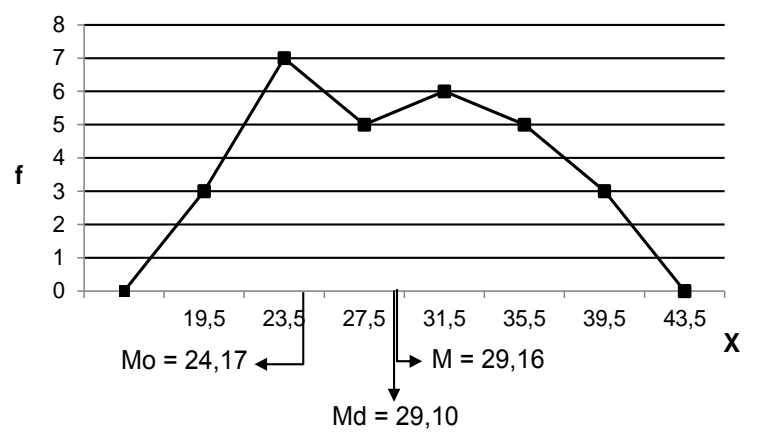

Gambar 2. Kurva Poligon Skor Post Test Kemampuan Pemecahan Masalah Matematka Kelompok Kontrol

Berdasarkan Gambar 2, diketahui bahwa mean lebih besar daripada median dan modus $(\mathrm{M}>\mathrm{Md}>\mathrm{Mo}$ ), sehingga kurva yang terbentuk yaitu kurva juling positif. Hal ini berarti sebagian besar skor cenderung rendah. Selanjutnya, berdasarkan hasil pengujian hipotesis, dapat diketahui bahwa thitung $(3,226)>t_{\text {tabel }}(2,000)$ pada taraf signifikansi $5 \%$. Sesuai dengan kriteria pengujian, apabila $t_{\text {hitung }}>t_{\text {tabel, }}$, maka $\mathrm{H}_{0}$ ditolak dan $\mathrm{H}_{1}$ diterima. Hal ini berarti bahwa terdapat perbedaan kemampuan pemecahan 
masalah Matematika antara kelompok siswa yang mengikuti pembelajaran menggunakan model Polya dan kelompok siswa yang mengikuti pembelajaran tidak menggunakan model Polya.

Berdasarkan hasil penelitian, dapat diketahui bahwa terdapat perbedaan kemampuan pemecahan masalah Matematika antara kelompok siswa yang mengikuti pembelajaran menggunakan model Polya dan kelompok siswa yang mengikuti pembelajaran tidak menggunakan model Polya. Hal tersebut ditunjukkan oleh perbedaan rata-rata skor dan hasil uji t. Perbedaan tersebut disebabkan oleh hal-hal berikut. Pertama, kelompok siswa yang mengikuti pembelajaran menggunakan model Polya diperkenalkan dengan pembelajaran pemecahan masalah. Adanya masalah yang berupa soal-soal nonrutin yang disajikan dalam pembelajaran membuat siswa aktif secara fisik dan mental untuk dapat memecahkan masalah tersebut. Siswa tampak gigih untuk dapat mencari penyelesaian masalah. Siswa juga dituntut untuk dapat memanggil kembali pengetahuan mereka mengenai konsep-konsep yang sesuai dengan permasalahan yang disajikan. Dengan demikian, pemahaman siswa akan meningkat sehingga kemampuan pemecahan masalah siswa pun menjadi lebih baik. Hal tersebut sesuai dengan pendapat Hensberry dan Jacobbe (2012:60-61) yang mengatakan bahwa, "problem solving aids in connecting the matematics learned to the real world, improves understanding, and can help to make mathematics accessible to struggling learners". Artinya, melalui pemecahan masalah, siswa dapat menghubungkan konsep Matematika yang telah dipelajari dengan kehidupan nyata, pemahaman siswa akan dapat meningkat dan siswa dapat tumbuh sebagai pelajar yang gigih.

Kedua, tahapan-tahapan model Polya melatih siswa untuk bekerja secara sistematis. Siswa dilatih untuk secara cermat membaca informasi yang terdapat pada soal. Siswa dituntun untuk dapat mengidentifikasi unsur-unsur yang diketahui dan ditanyakan pada soal. Hal tersebut membuat siswa memiliki dasar untuk memahami masalah yang disajikan. Dengan demikian, siswa mampu menentukan cara untuk memecahkannya. Hal tersebut sesuai dengan pendapat Billstein, dkk. (2007:3) yang menyatakan bahwa, "to solve a problem, we must first understand both the task and the given information. Next, it is helpful to determine a strategy to accomplish the task. Once we arrive at a solution, we should determine whether the solution makes sense and is reasonable". Artinya, dalam rangka memecahkan suatu masalah sudah tentu harus memahami masalah itu terlebih dahulu. Pemahaman terhadap suatu masalah akan bermanfaat untuk menentukan cara yang dapat dilakukan untuk menyelesaikan masalah. Setelah menemukan suatu jawaban atau solusi, perlu dilakukan peninjauan kembali tentang kebenaran jawaban atau solusi. Hal tersebut juga sesuai dengan hasil penelitian yang dilakukan Astriningsih (2015) yang menemukan bahwa keempat tahapan model Polya mampu menuntun siswa untuk memperoleh pengetahuan baru dan menemukan sendiri konsep-konsep yang dipelajari, sehingga kegiatan belajar menjadi berpusat pada siswa (student centered).

Ketiga, pembelajaran menggunakan model Polya yang didesain dengan membentuk kelompok kecil melatih siswa untuk bekerjasama dalam kelompok guna menyelesaikan tugas/LKS yang diberikan. Hal yang tampak yaitu siswa membagi tugas agar LKS yang diberikan dapat diselesaikan tepat waktu. Pembelajaran menggunakan model Polya dengan setting kelompok membuat siswa dapat bekerjasama dan berdiskusi untuk saling mengomunikasikan gagasan yang dimiliki. Hal ini sesuai dengan temuan penelitian yang dilakukan Dewi (2014:8) yang menjelaskan bahwa "model pembelajaran Polya membuat siswa mampu berpikir lebih kritis dan bekerjasama dalam memecahkan suatu permasalahan yang dipecahkan pada soal cerita matematika". Interaksi yang terjadi dalam proses diskusi membantu siswa mengembangkan wawasan, kreativitas dan kecerdasan sosial. Hal tersebut sesuai dengan pendapat Ruminiati (2008:2.5) yang menyatakan bahwa berdiskusi memiliki beberapa kebaikan yaitu, (1) dapat memperluas wawasan siswa, (2) dapat merangsang kreativitas siswa dalam memunculkan ide dalam memecahkan suatu masalah, serta (3) dapat mengembangkan sikap menghargai pendapat orang lain, (4) dapat menumbuhkan partisipasi siswa menjadi lebih aktif.

Selanjutnya, berkenaan dengan rata-rata skor kemampuan pemecahan masalah Matematika kelompok siswa yang mengikuti pembelajaran menggunakan model Polya yang berada pada kategori sedang dipengaruhi oleh beberapa hal berikut. Pertama, masalah atau soal yang disajikan kurang sesuai dengan tingkat perkembangan berpikir siswa. Meskipun siswa mampu mengidentifikasi unsur yang diketahui dan ditanyakan, namun siswa masih kesulitan dalam membuat rencana pemecahan masalah. Hal ini tidak terlepas dari pengalaman siswa yang minim tentang pemecahan masalah. Siswa masih terpaku dengan contoh cara pengerjaan yang diberikan guru, sehingga ketika konteks soal diubah maka siswa kesulitan untuk membuat rencana dan menyelesaikan soal tersebut. Kedua, alokasi waktu yang terbatas membuat siswa tidak dapat berpikir secara maksimal untuk dapat memahami dan menyelesaikan masalah yang disajikan. Pada pelaksanaan post test, ada beberapa soal yang tidak dijawab siswa, sehingga skor kemampuan pemecahan masalah Matematika siswa pun menjadi rendah. 


\section{Conclusion}

Berdasarkan hasil penelitian dan pembahasan, dapat disimpulkan bahwa terdapat perbedaan kemampuan pemecahan masalah Matematika antara kelompok siswa yang mengikuti pembelajaran menggunakan model Polya dan kelompok siswa yang mengikuti pembelajaran tidak menggunakan model Polya pada siswa kelas V SD di Gugus I Airlangga Kecamatan Mendoyo Tahun Pelajaran 2016/2017. Hasil pengujian hipotesis menunjukkan bahwa thitung $(3,226)$ lebih besar daripada tabel $(2,000)$ (thitung $>t_{\text {tabel }}$ ) yang diuji pada taraf signifikansi 5\% dengan dk 62 .

Saran-saran yang dapat diberikan kepada pihak-pihak terkait yaitu, kepada guru, hendaknya menyajikan masalah atau soal yang sesuai dengan kemampuan yang dimiliki siswa. Hal tersebut dapat dilakukan dengan melakukan identifikasi kemampuan awal yang dimiliki siswa melalui pemberian tes. Selain itu, guru hendaknya menambah referensi dan soal-soal pemecahan masalah dari berbagai sumber agar soal yang disajikan dapat lebih beragam. Kepada Kepala Sekolah, hendaknya mengikutsertakan guru dalam seminar atau pelatihan mengenai pembelajaran pemecahan masalah Matematika. Selain itu, Kepala Sekolah hendaknya mengupayakan untuk menambah referensi buku atau majalah dan sumber lainnya mengenai pembelajaran pemecahan masalah. Selanjutnya, kepada peneliti lain yang ingin melakukan penelitian tentang pemecahan masalah Matematika, hendaknya melakukan tes prasyarat untuk mengetahui kemampuan awal siswa. Hal tersebut berguna untuk dapat menentukan materi yang sesuai untuk dibelajarkan kepada siswa. Selain itu, disarankan pula untuk selalu memperhatikan waktu yang tersedia agar penelitian yang dilaksanakan dapat berjalan dengan lancar. Hal tersebut dapat dilakukan dengan melakukan koordinasi dengan kepala sekolah atau guru di tempat dilakukannya penelitian.

\section{Refferences}

Agung, A. A. Gede. 2014. Metodologi Penelitian Pendidikan. Edisi 2. Malang: Aditya Media Publishing. Aisyah, Nyimas, dkk. 2007. Pengembangan Pembelajaran Matematika SD. Direktorat Jenderal Pendidikan Tinggi Departemen Pendidikan Nasional.

Barb, Cynthia dan Anne Larson Quinn. 1997. "Problem Solving Does Not Have To Be A Problem". National Council of Teacher of Mathematics. Vol. 90, Issue: 7 (hlm. 536-542). Tersedia pada http://search.proquest.com/docview/201686584?accountid=38628. Diakses tanggal 12 Januari 2017.

Astriningsih, Ni Ketut. 2015. "Penerapan Model Polya Berbantuan Soal Cerita untuk Meningkatkan Hasil Belajar Matematika Siswa Kelas V Semester I". e-Journal MIMBAR PGSD Universitas Pendidikan Ganesha. Vol. $\quad 3, \quad$ No. $\quad 1 . \quad$ Tersedia pada http://ejournal.undiksha.ac.id/index.php/JJPGSD/article/download/6244/4368. Diakses tanggal 31 Januari 2017.

Billstein, Rick, dkk. 2007. A Problem Solving Approach to Mathematics for Elementary School Teacher. Ninth edition. United States of America: Pearson Education.

Dantes, Nyoman. 2012. Metode Penelitian. Yogyakarta: Andi Offset.

Dewi, Sari Kusuma. 2014. "Penerapan Model Polya untuk Meningkatkan Hasil Belajar dalam Memecahkan Soal Cerita Matematika Siswa Kelas V". Jurnal Mimbar PGSD Universitas Pendidikan Ganesha. Vol. 2, No. $1 . \quad$ Tersedia pada http://ejournal.undiksha.ac.id/index.php/JJPGSD/article/viewFile/2057/1794. Diakses tanggal 31 Januari 2017.

Hensberry, Karina K.R. dan Tim Jacobbe. 2012. “The Effect of Polya's Heuristic and Diary Writing on Children's Problem Solving". Mathematics Education Research Journal. Tersedia pada http://media.proquest.com/media/pq/classic/doc/4147824071/. Diakses tanggal 26 Januari 2017.

Japa, I Gusti Ngurah dan I Made Suarjana. 2014. Pendidikan Matematika I. Singaraja: Universitas Pendidikan Ganesha.

Marlina, Leni. 2013. "Penerapan Langkah Polya dalam Menyelesaikan Soal Cerita Keliling dan Luas Persegi Panjang". Jurnal Elektronik Pendidikan Matematika Tadulako. Vol. 01, No. 01 (hlm. 43-52). Tersedia pada http://jurnal.untad.ac.id/jurnal/index.php/jepmt/article/download/1708/1125. Diakses tanggal 23 Januari 2017.

Musser, Gary L., dkk. 2008. Mathematics for Elementary Teacher: A Contemporary Approach. United States of America: John Wiley \& Sons.

NCTM. 2000. Principles and Standards for School Mathematics. United States of America: NCTM. 
O’Daffer, Phares, dkk. 2008. Mathematics for Elementary School Teacher. Fourth Edition. United States of America: Pearson Education.

OECD. 2016. Low Performing Students: Why They Fall Behind and How to Help Them Succeed. Paris: OECD Publishing. Tersedia pada http://dx.doi.org/10.1787/9789264250246-en. Diakses tanggal 31 Januari 2017.

Prihandoko, Antonius Cahya. 2005. Memahami Konsep Matematika secara Benar dan Menyajikannya dengan Menarik. Direktorat Jenderal Pendidikan Tinggi.

Ruminiati. 2008. Pengembangan Pendidikan Kewarganegaraan SD. Direktorat Jenderal Pendidikan Tinggi Departemen Pendidikan Nasional.

Sugiyono. 2010. Statistika untuk Penelitian. Bandung: Alfabeta. 